\title{
INVESTIGATION OF CHANGES OF STRUCTURAL-MECHANICAL PROPERTIES OF FATTY FILLING FOR SYNBIOTIC WAFERS
}

\author{
Hanna Korkach \\ Department of Bakery, confectionary, macaroni products and food concentrate technologies \\ Odessa National Academy of Food Technologies \\ 112 Kanatna str., Odessa, Ukraine, 65000 \\ kor2007@ukr.net
}

\begin{abstract}
There was grounded the choice of functional ingredients for creating the synbiotic complex, consisted of immobilized bifidobacteria and inulin. There was demonstrated the necessity to realize the process of immobilization for "defending" bifidobacteria cells from the effect of unfavorable factors. There was determined the number of microorganisms' cells and mass share of inulin for introducing in the recipe of a fatty filling.

There was studied the influence of synbiotics on structural-mechanical properties of a fatty filling for wafers. The limit speed, that the high-quality filling can be received at, was established, according to experimental data. It was studied, that the decrease of the fat quantity in the mass and simultaneous increase of the solid phase leads to the increase of the filling firmness that allows to shorten of the process of wafer layers cooling.

There was grounded the expedience of using the synbiotic complex in the technology of wafers fatty filling that allows to receive new wafer types of the functional directionality.
\end{abstract}

Keywords: immobilized bifidobacteria, inulin, synbiotic, fatty filling, wafers.

\section{Introduction}

The last years on the background of the progressing environment pollution, stress situations development, increase of antibiotics and anti-tumor preparations consumption, the increase of dysbacteriosis morbidity in people takes place [1]. The treating food occupies the one of leading places in the complex therapy of intestine dysbacteriosis.

Modern tendencies of the healthy food ration formation dictate the necessity to create enriched products that provide the support and activation of human vitally important functions. So, the consumers' use of the wide spectrum of food products with treating-prophylactic properties that favor the intestine microflora normalization can decrease the spreading of dysbacteriosis essentially [2-4].

The prophylaxis and treatment of dysbacteriosis are connected with the renewal of normal intestine microflora using pharmacopeial preparations: biologically active additives; functional food products that contain probiotics, prebiotics and synbiotics. The main probiotics are bifidoand lactobactria. Bifidobacteria are natural dwellers of the thick intestine in children and adults, at that, lots of types have many positive effects on the owner's organism [5]. The life activity of bifidobacteria: decelerates the intestine cancer cells growth; inhibits the activity of putrefactive and pathogenic bacteria; stimulate vitamins production; activates immune processes; provides the defense from the intestine infection; takes part in the assimilation of nutritive substances, vitamins and microelements [6-8].

Products that contain prebiotics and synbiotics are also used for the prophylaxis of dysbacteriosis. Prebiotics - functional ingredients that provide the growth and/or biological activity of normal microflora of the intestine tract. At that the health status improvement is noted. Synbiotics - is the complex of pro- and prebiotics which influence on the human organism is based on the symbiosis of these ingredients.

Having realized the analysis of the literary sources [9-13], we came to the conclusion about the use of these groups of ingredients in the technology of confectionary products. The aim of the work is the elaboration of the new synbiotic complex, its introduction to the recipe of the fatty fill- 
ing for wafers and the study of the influence on structural-mechanical properties on a semi-product. It allows to substantiate the expedience of using synbiotics at the fatty filling production.

\section{Materials and Methods}

The studies were carried out at the department of "Technology of Bakery, confectionary, macaroni products and food concentrate technologies" of Odessa National Academy of Food Technologies.

The object of the study - are organoleptic, physical-chemical properties of the fatty filling for wafers. The subject of the study - is the fatty filling for wafers with the synbiotic complex - microcapsuled bifidobacteria were used as a probiotic (Fig. 1), inulin - as a prebiotic (Fig. 2). Samples differed by the mass share of inulin (10, 20 and $30 \%$ of inulin) (Fig. 3). "Artek" wafers were used as a control [14].

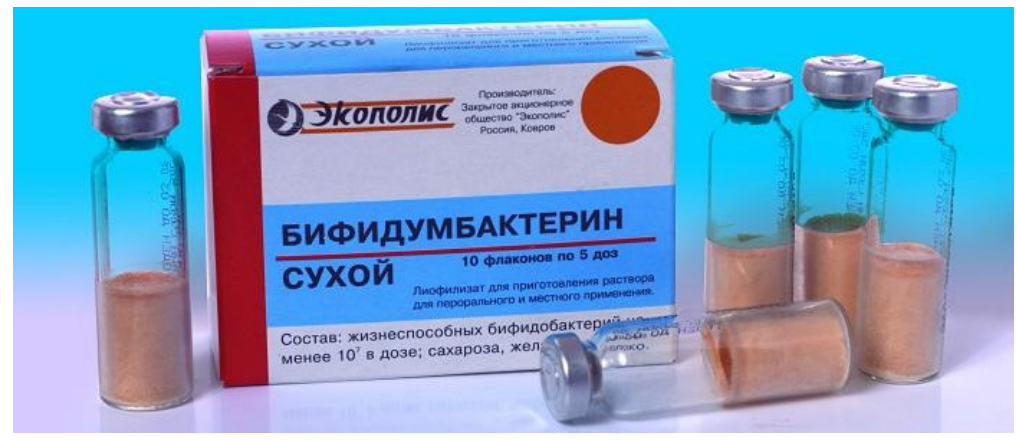

Fig. 1. Lyophilized bifidobacteria

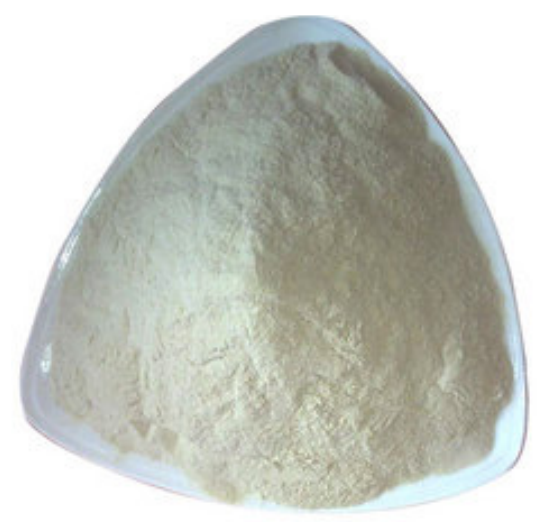

Fig. 2. Inulin powder

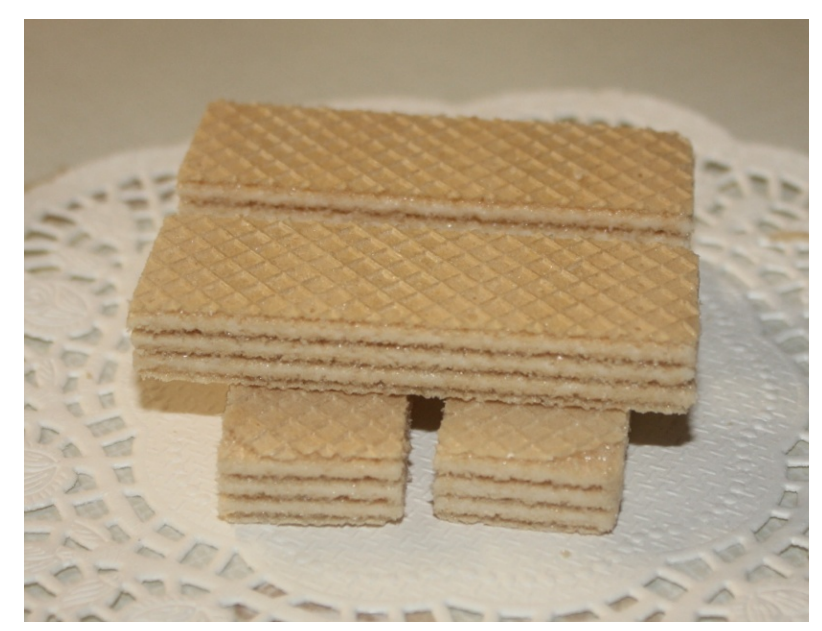

Fig. 3. Experimental samples of wafers with inulin 
The following raw materials were used at the experiments for elaborating the fatty filling for wafers (Table 1).

Table 1

Raw materials for wafers production

\begin{tabular}{ccc}
\hline $\begin{array}{c}\text { Raw material name, } \\
\text { country-producer }\end{array}$ & $\begin{array}{c}\text { Raw material quantity for } \\
\mathbf{1} \text { t of ready products, kg }\end{array}$ & Normative document name \\
\hline Flour of 1 st $^{\text {sort (Ukraine) }}$ & 262,25 & USST 46.094:99 \\
Yolk (chicken eggs) (Ukraine) & 26,23 & USST 5028:2008 \\
Salt (Ukraine) & 1,31 & USST 3583:97 \\
Soda (Ukraine) & 1,31 & SST r107:v \\
Sugar powder (Ukraine) & 412,24 & USST 4623:2006 \\
Confectionary fat (Ukraine) & 192,38 & USST 4463:2005 \\
Essence (Ukraine) & 2,06 & USST 4910:2008 \\
Citric acid (Ukraine) & 2,06 & USST SST 908:2006 \\
Inulin of chicory root (Netherland) & 85.7 & (“Sensus B. V.”) \\
Bifidumbacterin (Ukraine) & 0,55 & U TC 10.8-40386419-001:2016
\end{tabular}

Salt $\mathrm{CaCl}_{2}$ was used as a source of $\mathrm{Ca}^{2+}$. For preparing $\mathrm{CaCl}_{2}$ solution, the calculated amount of the substance was dissolved in distilled water at $\mathrm{t}=18 \ldots 20^{\circ} \mathrm{C}$ during $\tau=(8 \ldots 10) \times 60 \mathrm{~s}$ (for solving the salt batch), the received solution was filtered through the filter.

Microcapsuled bifidobacteria were prepared as following. Low-etherified pectin (in amount $0,9 \mathrm{~g}$ ) and distilled water (in amount $15 \mathrm{ml}$ ) were mixed on the magnetic mixer at the temperature $36-38{ }^{\circ} \mathrm{C}$ during 10 minutes. Dissolved pectin was added with preliminary dissolved bifidobacteria and mixed again during $10 \mathrm{~min}$. The received homogenous mixture was added with $10 \%$ solution of $\mathrm{CaCl}_{2}$, then the mass was accurately mixed during one more $10 \mathrm{~min}$. After receiving capsulated bifidobacteria, the mixture was percolated, and ready microcapsules were kept in quiet for $30 \mathrm{~min}$ (the methodology was elaborated during the realized studies).

\section{1. Experimental procedures}

The determination of viscosity was realized on the rotary viscosimeter "Rheotest-2" by RHEOTEST Medingen GmbH (Germany) (Fig. 4). This viscosimeter is completely automated that gives a possibility to obtain reliable data with the least mistake on the dial on the measuring device. The principle of its action is in the measuring of the turning moment of the cylinder that moves in the studied mass that is in the immovable cylinder.

Before starting the measurement, the zero point control is realized. Then the measuring tank is filled with the studied product.

The liquid material viscosity mainly depends on the temperature. For this aim the measuring tank with the studied substance is tempered during the experiment.

There is the ratio between indications of the device and rheological parameters, expressed in the equation:

$$
\tau=\mathrm{Z} \cdot \mathrm{a},
$$

where $\tau$ - the shift tension, $\mathrm{Pa} ; \mathrm{Z}$ - the stable constant of the cylinder, $\mathrm{Pa} /$ un of the device; $\mathrm{a}-$ the indications of the device scale, un of the device.

The fall of the speed in the ring-shaped gap indicates the tension gradient on the cut $\mathrm{D}_{\mathrm{r}}\left(\mathrm{s}^{-1}\right)$, called deformation speed. This gradient depends on sizes of the system of cylinders, proportional to the number of turns of the turning cylinder. 


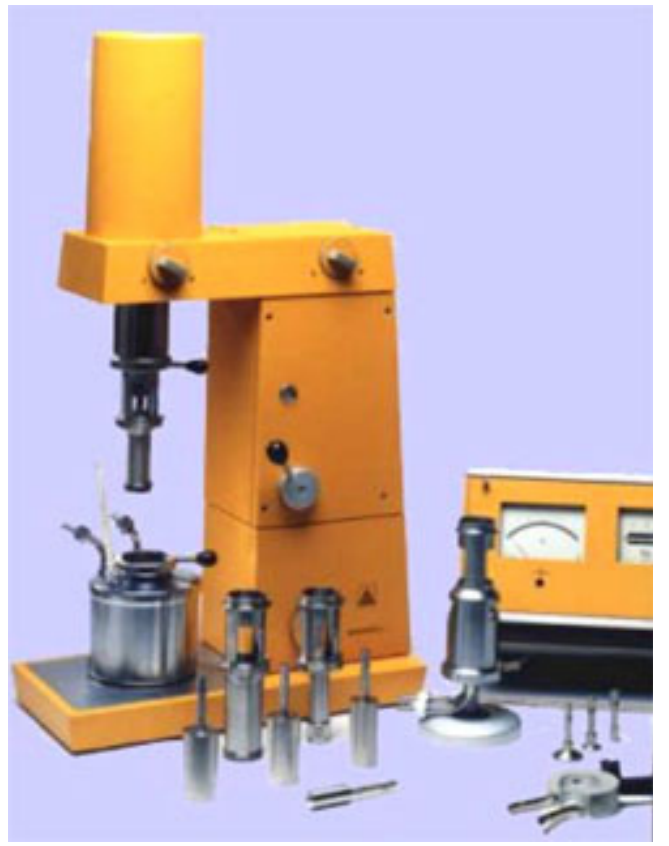

Fig. 4. $\mathrm{P}=$ Rotary viscosimeter "Rheotest-2" (Germany)

The dynamic viscosity is determined by the measurement of the shift tension $\tau$ and tension gradient $\mathrm{D}_{\mathrm{r}}$ :

$$
\eta=\tau / D_{r}
$$

where $\eta$ - the dynamic viscosity, Pa·s; $\tau$ - the shift tension, N/m ${ }^{2} ; \mathrm{D}_{\mathrm{r}}$ - the tension gradient for the cut, $\mathrm{s}^{-1}$.

Adhesion is understood as a phenomenon of the sticking of materials of different structures at their surface contact, with so-called adhesive connection as a result. In the processes of food productions the contact interaction between a material and working body surfaces of machines, devices and apparatuses take place. At studying and improving technological processes, it is necessary to take into account surface properties of food materials, especially adhesion and external rubbing.

The formation of the adhesion connection between the food and constructive material is mainly influenced by rheological properties, roughness of contacting surfaces, duration and tension of the contact, temperature of the food mass and surface, way and speed of the separation.

For characterizing adhesion properties, the value of adhesion firmness, adhesion tension - T, determined as the separation power $-\mathrm{P}$, related to the contact area $-\mathrm{S}$, is used.

Adhesiometers, different by methods of the load application and separation, are used for measurements.

The scheme of the adhesiometer, developed at the Odessa academy of food technologies, is presented on Fig. 5. The order of the work on the device is following: the experimental mass with the certain humidity and temperature is placed in chamber 1. Plate 2 is lowered on the mass surface, contact duration is fixed by the stopwatch, then electric motor 3 is switched on. At that plate 2 is raised vertically up, separating from the experimental mass. The separation effort, determined using tensoresistors 4 , is fixed by indications of miliampermeter 5 .

The adhesion firmness for the separation was determined by the dependence:

$$
\mathrm{T}=\frac{\mathrm{P}}{\mathrm{S}},
$$

where $\mathrm{T}$ - the specific resistance to the separation, $\mathrm{Pa} ; \mathrm{P}$ - the effort for the separation, $\mathrm{kg} ; \mathrm{S}-$ the area of the contact between the confectionary mass and surface, $\mathrm{m}^{2}$ 
The limit shift tension was determined on the penetrometer (Fig. 6).

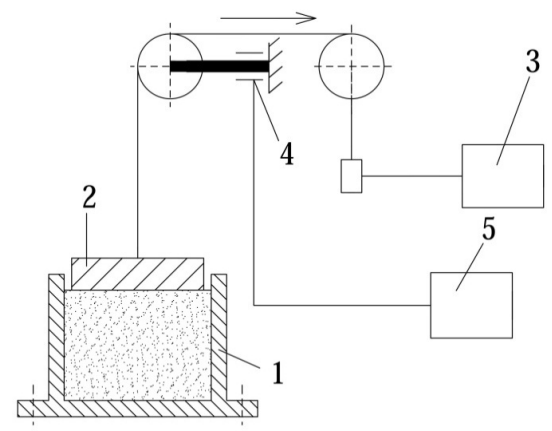

Fig. 5. Adhesiometer scheme: 1 - chamber for determination; 2 - plate for the contact with the experimental mass and separation: 3 - electric motor; 4 - tensoresistors; 5 - miliampermeters

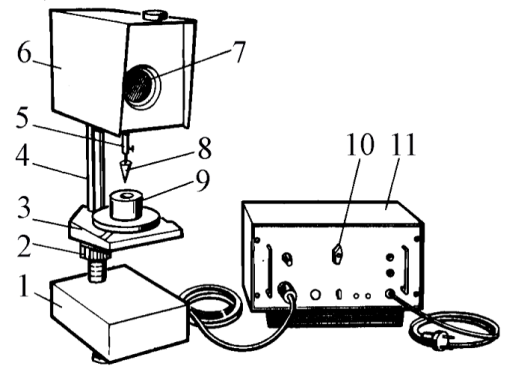

Fig. 6. Penetrometer AP-4/1: 1 - main plate, 2 - nut, 3 - measuring table, 4 - vertical stand, 5 - bush, 6 - measuring capping, 7 - microscale for reading indications, 8 - immersion body - indenter, 9 - glass

Penetration is the method of the determination of structural-mechanical properties of semi-products and ready products by establishing the penetration of an immersion body with distinctly fixed sizes, mass and material at the distinctly set temperature for the certain time. An immersion body can look as a ball, needle, cylinder, cone. There are distinguished penetration itself, when the immersion depth of a tip doesn't exceed its height, and probing, when the immersion depth exceeds its height.

The results of penetration studies are objective characteristics that reflect the material resistance to the compression and shift. The main value, obtained at penetration, is the limit shift tension, which index can be determined by Rebinder formula:

$$
\tau=\left(\mathrm{K} \alpha \cdot \mathrm{P} / \mathrm{h}^{2}\right) \cdot 9,8
$$

where $\mathrm{h}$ - the height of the cone immersion (m); K $\alpha$ - the cone constant that depends on the angle $\alpha$ at the vertex, $\alpha=60^{\circ} ; \mathrm{K} \alpha=0,244 ; \mathrm{P}$ - the penetration effort $(\mathrm{N})$, (mass of the cone, bush and immersion system), $\mathrm{P}=0,085 \cdot 9,8=0,833 \mathrm{~N}$ ).

The filling density was determined by the method [15]. The received filling was poured in the dry bux of the set volume, excesses were taken away by the palette knife and left in quiet for 5 min. The filling density $\rho\left(\mathrm{kg} / \mathrm{m}^{3}\right)$ was calculated by the formula:

$$
\rho=\frac{m_{1}-m_{2}}{v} \cdot 1000
$$

where $\mathrm{m}_{1}$ - the mass of the bux with the filling, $\mathrm{g} ; \mathrm{m}_{2}$ - the mass of the empty bux, $\mathrm{g}$; $\mathrm{v}-\mathrm{the}$ bux volume, $\mathrm{cm}^{3}$. 


\section{Results}

At the first stage of the research the methods of bifidobacteria "defense" from the influence of technological and physiological factors were studied. The biomass of bifidobacteria was microcapsulated $[16,17]$. The microcapsulated form gives prebiotic bacteria strains the high antagonistic activity to different types of pathogenic microorganisms, resistance to the effect of unfavorable factors, to digestive enzymes, allows to regulate the speed of capsules content release in the place of dislocation.

At the experiments, the optimal mass share of inulin and quantity of immobilized bifidobacteria, stage of the additive introduction at preparing the filling were determined, the influence of the synbiotic complex on organoleptic and rheological quality parameters was studied.

The one of rheological characteristics that determines the filling quality is viscosity (internal rubbing) - the measure of resistance to the flow. Viscosity mainly depends on the temperature of the studied mixture. Before being put on the smearing machine, the ready filling is kept in the tempered collector at the temperature $35^{\circ} \mathrm{C}$.

The realized researches demonstrated that the addition of synbiotic to the filling leads to the raise of the effective viscosity.

The synbiotic complex influence on the filling firmness was determined on the penetrometer. The change of the limit shift tension was determined at the duration of structure creation from 0 to 14 minutes each 2 minutes. The obtained experimental results are presented in Table 2 .

\section{Table 2}

The influence of the synbiotic additive on the fatty filling firmness properties depending on the structure creation time

\begin{tabular}{ccccc}
\hline Time of structure creation, min & \multicolumn{4}{c}{ The shift tension $\boldsymbol{\tau}, \mathbf{k P a}$, at inulin content, \% and microcapsulated bifidobacteria } \\
& Control & $\mathbf{1 0} \%$ & $\mathbf{2 0} \%$ & $\mathbf{3 0} \%$ \\
\hline 0 & 1,07 & 0,96 & 1,07 & 1,1 \\
2 & 1,09 & 1,17 & 1,26 & 1,35 \\
4 & 1,14 & 1,38 & 1,46 & 1,56 \\
6 & 1,35 & 1,49 & 1,92 & 3,04 \\
8 & 1,53 & 1,71 & 2,7 & - \\
10 & 1,57 & 1,76 & - & - \\
12 & 1,62 & 2,2 & - & -
\end{tabular}

The experimental data testify that the filling of the control sample gains the necessary firmness in 14 minutes, whereas in the studied samples this term is $8-12$ minutes. That is the increase of the filling firmness at adding the synbiotic complex takes place at the expanse of the increase of solid particles and decrease of the thickness of the fatty layer in the fatty mass.

At the fatty filling production the great importance is inherent to the degree of its adhesion to the production equipment surface and dense contiguity of the wafer plate to the filling. The change of the specific force of the plate separation from the filling mass with the different additive content was studied on the adhesiometer. The analysis of the expetimental data demonstrates that the synbiotic introduction into the filling leads to the increase of the force of the forming surface separation from the fatty filling, that is most likely, connected with the increase of the plasticity of the filling that is distributed better along the area of the wafer plate.

At the work there were studied the change of the wafer filling density depending on the additive quantity. The experimental data demonstrate that the filling density in the experimental samples increases. Thus, in the control sample it is $770 \mathrm{~kg} / \mathrm{m}^{3}$, whereas in samples $10 \%, 20 \%$ and $30 \%$ of inulin 790,820 and $880 \mathrm{~kg} / \mathrm{m}^{3}$, respectively. The decrease of the fat mass share that favors the mass saturation with air takes place in experimental samples. So, the increase of the density of the studied samples comparing with the control one takes place. 


\section{Conclusions}

Based on the analysis of technological and physiological properties of inulin and bifidobacteria, there was substantiated the expedience of the synbiotic complex creation and its use in the wafer products technology.

The elaborated fatty filling for wafer products with the synbiotic allows to supply the human organism not only with the energetic and plastic material, but to control concrete physiological functions. These functions are directed on the intestine microflora normalization, favor the increase of the human immunity.

The use of the synbiotic complex in the fatty filling technology allows to receive the technological effects: to improve structural-mechanical properties of the filling, to shorten the process of structure creation, favors the plasticity increase. As a result wafer products will keep their form during the whole storage term and will not exfoliate.

Based on the realized researches, there were elaborated the recipe, technological scheme, project of technological instructions and technological conditions for the experimental batch of wafers "Perl". The industrial probations were realized at "Agrobusiness" and "Chervony Karavay" LTD (Ukraine).

\section{References}

[1] Solov'eva, N. V., Leyhter, S. N., Bazhukova, N. F., Solov'ev, A. G., Lebedeva, O. V. (2010). Korrektsiya disbioticheskih narusheniy pri zabolevaniyah zheludochno-kishechnogo trakta i pecheni biologicheski aktivnymi dobavkami s probioticheskim deystviem. Obzory po klinicheskoy farmakologii i lekarstvennoy terapii, 8 (3), 48-57.

[2] Kapreliants, L. V., Iorhachova, K. H. (2003). Funkcionalni produkti. Odessa: Druk, 312.

[3] Tihomirova, N. A. (2002). Tekhnologiya produktov funktsional'nogo pitaniya. Moscow: Frantera, 213.

[4] Didukh, N. A., Chaharovskyi, O. P., Lysohor, T. A. (2008). Zakvashuvalni kompozytsii dlia vyrobnytstva molochnykh produktiv funktsionalnoho pryznachennia. Odessa: Poligraf, 236.

[5] Cheikhyoussef, A., Pogori, N., Chen, W., Zhang, H. (2008). Antimicrobial proteinaceous compounds obtained from bifidobacteria: From production to their application. International Journal of Food Microbiology, 125 (3), 215-222. doi: 10.1016/j.jifoodmicro.2008.03.012

[6] Shenderov, B. A. (2001) Meditsinskaya mikrobnaya ekologiya i funktsional'noe pitanie. Vol. 3: Probiotiki i funktsional'noe pitanie. Moscow: Grant, 288.

[7] Biavati, B., Mattarelli, P. (2006). The Family Bifidobacteriaceae. The Prokaryotes, 322-382. doi: 10.1007/0-387-30743-5_17

[8] Piksasova, O. V., Kornienko, M. A., Tsygankov, Yu. D., Netrusov, A. I. (2009). Methods of Molecular Identification as Important Tools for Control and Certification in Microbioligy. Electronic Journal of Natural Sciences, 1, 35-49.

[9] Krasina, I. B., Hashpakyants, E. A., Dzhahimova, O. I. (2014). Vliyanie probiotikov i prebiotikov na reologicheskie svoystva strukturirovannyh dispersnyh sistem. Fundamental'nye issledovaniya, 6, 1149-1153.

[10] Konar, N., Toker, O. S., Oba, S., Sagdic, O. (2016). Improving functionality of chocolate: A review on probiotic, prebiotic, and/or synbiotic characteristics. Trends in Food Science \& Technology, 49, 35-44. doi: 10.1016/j.tifs.2016.01.002

[11] Erdem, O., Gultekin-Ozguven, M., Berktas, I., Ersan, S., Tuna, H. E., Karadag, A. (2014). Development of a novel synbiotic dark chocolate enriched with Bacillus indicus HU36, maltodextrin and lemon fiber: Optimization by response surface methodology. LWT - Food Science and Technology, 56 (1), 187-193. doi: 10.1016/j.lwt.2013.10.020

[12] Mandal, S., Hati, S., Puniya, A. K., Singh, R., Singh, K. (2013). Development of synbiotic milk chocolate using encapsulated Lactobacillus casei NCDC 298. Journal of Food Processing and Preservation, 37 (5), 1031-1037. doi: 10.1111/j.1745-4549.2012.00759.x

[13] Chonova, V. (2013). Vzmozhnosti za prilozhenie na probiotitsi v hleboproizvodstvoto i sladkarstvoto. Nauchni trudove na Rusenskiya Universitet, 52 (10.2), 213-218.

[14] Recepturi na pechivo ta galeti (1999). Kyiv: Ukrkonditer, 143. 
[15] Lur'e, I. S. (1978). Rukovodstvo po tekhnologicheskomu kontrolyu v konditerskoy promyshlennosti. Moscow: Pishchevaya promyshlennost, 278.

[16] Korkach, A. V., Krusir, G. V., Borovik, I. A. (2014). Possibilities of using synbiotic complex in marshmallow technology of functional purpose. Eastern-European Journal of Enterprise Technologies, 2 (12 (68)), 127-133. doi: 10.15587/1729-4061.2014.23665

[17] Korkach, H., Krusir, G. (2017). Development of innovative technologies of fondant candies with synbiotics. Technology Audit and Production Reserves, 1 (3 (33)), 50-55. doi: 10.15587/2312-8372.2017.93806

\title{
INVESTIGATION OF FOAMING AND HYDRATION PROPERTIES OF COLLAGEN HYDROLYZATE
}

\author{
Nadya Dzyuba \\ Department of restaurant and health food technology \\ Odessa National Academy of Food Technologies \\ 112 Kanatna str., Odessa, Ukraine, 65039 \\ dzyubanadya282@gmail.ru \\ Iryna Bilenka \\ Department of restaurant and health food technology \\ Odessa National Academy of Food Technologies \\ 112 Kanatna str., Odessa, Ukraine, 65039 \\ irinabelenka@gmail.com \\ Anna Palvashova \\ Department of biotechnology, preserved food and beverages \\ Odessa National Academy of food technologies \\ Kanatnaya str., 112, Odesa, Ukraine, 65039 \\ palvashova_ai@ukr.net \\ Elena Zemlyakova \\ Department of restaurant and health food technology \\ Odessa National Academy of Food Technologies \\ 112 Kanatna str., Odessa, Ukraine, 65039 \\ elenazemlyakova00@gmail.com
}

\begin{abstract}
Qualitative parameters of foams, received due to glutin were studied. Technological conditions for receiving food foams were optimized. Their microstructure was determined; it was demonstrated that foam bubbles have the spherical form with the size from $50 \mathrm{mcm}$ to $200 \mathrm{mcm}$ (at the shaking temperature $9^{\circ} \mathrm{C}$ ), at increasing the temperature of foam creation to $20^{\circ} \mathrm{C}$, the mean bubble size reaches $1530 \mathrm{mcm}$.

The data, obtained using IR-spectroscopy demonstrated the presence of free groups, able to bind free water molecules. The obtained microphotos of hydrated glutin demonstrated that the crystal form had not been destructed by the alkaline hydrolysis, partially dissolved at hydratation.

The obtained data give a possibility to recommend collagen hydrolyzate as an effective foaming agent and stabilizer of food systems at producing beverages of raw material fruits.
\end{abstract}

Keywords: rheological properties of food foams, microphoto, collagen hydrolyzate, glutin.

DOI: $10.21303 / 2504-5695.2017 .00424$

(C) Nadya Dzyuba, Iryna Bilenka, Anna Palvashova, Elena Zemlyakova

\section{Introduction}

The last time the worsening of the food status of the population, especially dwellers of megalopolises and unfavorable regions, causes the special interest. The stable deficit of macro- and 